\title{
Using of Calcined Clay in soil subbase materials
}

\author{
Kamal G. Sharobim ${ }^{1}$, M.EL Gendy ${ }^{2}$, Nesreen Elawadly ${ }^{3}$ \\ 1 Professor of Properties and Strength of materials, \\ Civil Department, Faculty of Engineering, Suez Canal University, \\ Ismailia, Egypt, k_sharobim@ hotmail.com. \\ 2 Professors of Geotechnical and Foundation Engineering, \\ Civil Department, Faculty of Engineering, Port Said University, \\ Port Said, Egypt,melgendy@elpla.com. \\ 3 teaching assistant, Civil Engineering Departments, \\ New Damietta Higher Institute of Engineering and Technology, \\ Damietta, Egypt,zakaria.nesren@gmail.com.
}

\begin{abstract}
The paper presents results of study on soil subbas improvement. The main object of the study was using the recycled calcined clay to get rid of it by a useful friendly environmental method. Big amount of waste refractory bricks were outcome with Portland cement manufacturer. The study presents recycling this waste calcined clay with crushing it into graded aggregates. Coarse crushed (CR) and fine crushed (FR) recycled calcined clay were the products which studied. Kaolin (KA) and Metakaolin (MK) were two other types of calcined clay materials have been studied in this paper to find out it's suitability as a subbase improvement materials. Two original soil samples were used. The first was an original clayey soil from the surface layer of south Port said, Egypt and the second soil sample was an original sandy soil from the surface layer of Port Fouad, Port Said, Egypt. The scope of the search was to mix original soil with $20 \%$ calcined clay. Eight improved samples containing calcined clay with $20 \%$ were prepared. Soil properties, sieve analysis and California bearing ratio test (CBR) were checked against the original soil samples. The study recommended recycled calcined clay as an improvement material.
\end{abstract}

Keywords: Subbase improvement, Calcined Clay, recycled refractory brick, Kaolin, Metakaolin.

\section{INTRODUCTION}

In recent years, researchers from many fields have attempted to solve soil problems by industrial wastes. Finding a way for the utilization of these wastes would be an advantageous way of getting free of them. Recent projects illustrated that successful waste utilization could result in considerable savings in construction costs [2] It is an age-old practice to use lime in one form or the other to improve the engineering behavior of clayey soils. [1] Sabat and Nada use the Quarry Dust to make soil stabilization. [3], [4]. Ene and Okagbue use pyroclastic dust to improve some kind of soil [5], Abd EI Aziz and Abo-Hashema use brick powder [6]. Binici use the waste of ceramic industry [7] Koyuncu et. Use ceramic tile dust wastes up to $40 \%$. [8]. P. Indiramma and Dr .Ch.Sudharani find from them search that it can be inferred that Quarry Dust can be used as stabilizing admixture for expansive soil also. [9].

paper, adjust the lengths of the columns so that they are equal. Use automatic hyphenation and check spelling. Digitize or paste down figures.

\section{MATERIALS AND METHODS}

Waste calcined clay was fine (FR) and coarse (CR) crushed refractory brick. It was a waste material from" Helwan cement factory for Portland cement production". The factory located in Helwan city in Egypt .getting rid of the waste refractory bricks presented a problem to the factory. The refractory brick crushed with a hummer into small to big graded pieces as fine and coarse aggregate (figure1). Those two calined clay types fine and coarse recycled were mixed with original soil in a replacement ratio of $20 \%$ replacement.

Two original soil samples were used. First original soil sample was sandy soil taken from surface layer of Port Fouad, Port Said, Egypt. The other original soil sample was clayey soil taken from South Port Said, Egypt. (fig.2) and (fig 3)

Other two types of calcined clay were Metakaolin (MK) and kaolin (KA). Kaolin and Metakaolin were produced by" Asfour factory for mining and refractories" located in Helwan city in Egypt. Kaolin fired up to the temperature of $1000{ }^{\circ} \mathrm{K}$ and Metakaolin fired up to the temperature of $600{ }^{\circ} \mathrm{K}$, the physical and chemical properties of kaolin and Metakaolin were shown in table (I) to table (III) depending on Asfour factory datasheets.

A. $\quad$ Mixing soil with calcined clay types in feild

Soil mixing is categorized into two methods: dry soil mixing or wet soil mixing. Soil mixing is best suited for clay. There are number of soil mixing methods with a binder such as lime, cement, or slag is mixed with the in situ material to improve its strength characteristics. These methods may be used to mix recycled calcined brick, kaolin and metakaolin with soil.

\section{B. For the depth from soil surface to $2.0 \mathrm{~m}$}

Number Soil-cement is the most rudimentary method which has been used for decades as a construction material to increase the strength of roadway subgrades. The same way of mixing cement with soil may be used because of this reason. Suggested in feild methods are jet grouting and dry soil mixing.

Jet grouting could be ideal for stabilizing existing roadways as it uses a small-diameter drill stem to inject high pressure grout out the side of a cutting. This produces a 
column of improved soil. Dry soil mixing is a technique which can be performed on shallow soil deposits using machines to mix the soil with the improvement materials.

\section{For the depth of 3.0 m or more}

The For the depth of $3.0 \mathrm{~m}$ or more a number of methods may be suitable for mixing graded recycled bricks, kaolin or met kaolin. It is possible to excavate and replace the soil surface layer with the mixture of original soil and recycled brick. This can be an expensive method which may require dewatering, sheet pile support, or both. The final decision is due to project importance.

Other techniques may be suitable such as small stone columns, sand columns and dynamic replacement and soil mixing. The idea of stone columns may be used it is a semirigid inclusions installed by progressively packing sand or stone which will be replaced by recycled calcined clay the material installed into a borehole formed by a vibrating electric motor within a probe at the end of a long steel stem..

\section{SPECIMEN PREPARING}

Ten soil samples prepared in the study. The first and second soils were the original soils without any improvement. The other eight soils were the improved soils. $80 \%$ of each sample mixed with $20 \%$ of one type of calcined clay types. Table (V) shows soil sample definition and proportion. The waste recycled refractory bricks were crushed into fine and coarse graded pieces using a hammer, Fine recycled refractory brick size was from $0.15 \mathrm{~mm}$ to $4.75 \mathrm{~mm}$ and Coarse recycled refractory brick size was from $4.75 \mathrm{~mm}$ to $13.2 \mathrm{~mm}$. The soil was mixed with $20 \%$ of each four calcined clay types. Tests were conducted on these samples according to relevant Egyptian Standard ECP 202/2.Some Common Mistakes

Soil properties, sieve analysis were done for ten soil samples. California bearing ratio test (CBR) was done to find out the suitability of calcined clay types as an improvement materials.

TABLE I

PHYSICAL COMPOSITION OF METAKAOLIN

\begin{tabular}{|c|c|}
\hline Element & Result $\%$ \\
\hline L.O.I & $6-7 \%$ \\
\hline $\mathrm{A} 12 \mathrm{O} 3$ & $28-31 \%$ \\
\hline $\mathrm{SiO} 2$ & $57-60 \%$ \\
\hline $\mathrm{Fe} 2 \mathrm{O} 3$ & $1.5-1.7 \%$ \\
\hline $\mathrm{TiO} 2$ & $1.5-2.5 \%$ \\
\hline $\mathrm{CaO}$ & $1 \% \mathrm{Max}$ \\
\hline $\mathrm{Mg} \mathrm{O}$ & $0.2 \% \mathrm{Max}$ \\
\hline $\mathrm{Na} 2 \mathrm{O}+\mathrm{K} 2 \mathrm{O}$ & $0.3 \% \mathrm{Max}$ \\
\hline Sieve Analysis & $\max >500 \mu=3 \%$ \\
\hline
\end{tabular}

TABLE II

PHYSICAL PROPERTIES OF KAOLIN

\begin{tabular}{|c|c|}
\hline Grain size distribution & Percentage $\%$ \\
\hline$>100 \mu$ & $0.5-2$ \\
\hline$>63 \mu$ & $17-22$ \\
\hline$<63 \mu$ & $75-82$ \\
\hline
\end{tabular}

TABLE III

CHEMICAL COMPOSITION OF KAOLIN

\begin{tabular}{|c|c|}
\hline Chemical composition & Percentage $\%$ \\
\hline $\mathrm{AL} 2 \mathrm{O} 3$ & $36-40$ \\
\hline $\mathrm{Fe} 2 \mathrm{O} 3$ & $1.3-1.8$ \\
\hline $\mathrm{SiO} 2$ & $54-58$ \\
\hline $\mathrm{TiO} 2$ & $1.5-2.5$ \\
\hline $\mathrm{CaO}$ & $0.3-0.4$ \\
\hline $\mathrm{MgO}$ & $0.1-0.2$ \\
\hline $\mathrm{K} 2 \mathrm{O}+\mathrm{NaO}$ & $0.2-0.4$ \\
\hline
\end{tabular}

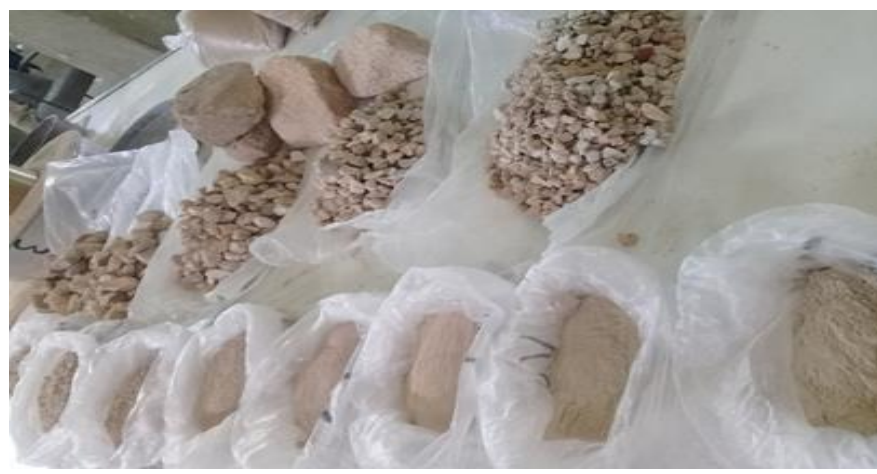

Figure 1. Graded recycled refractory brick

\section{SPECIMEN RESULTS AND DISCUSSION}

Depending on results of grain size analysis, Atterberg's limits (liquid limit, plastic limit) and the most important test for subbase improvement soil was (CBR) California bearing ratio test. The California bearing ratio test was penetration test meant for the evaluation of subgrade strength of roads and pavements by the laboratory. Using grain size Analysis, and Atterberg's limits for the first original soil (OC) the results show $67.2 \%$ passed from sieve No. 200(0.075 mm) and according to AASHTO classification, the soil (OC) classified as class [A-7] clayey soil, fair to poor subgrade soil. It is known that most of the soil of south Port Said is a poor weaken soil

TABLE IV

RESULTS OF ORIGINAL CLAYEY SOIL (OC) AND FOUR IMPROVED CLAYEY

\begin{tabular}{|c|c|c|c|c|c|c|c|c|}
\hline \multicolumn{9}{|c|}{ SOILS } \\
\hline \multicolumn{2}{|c|}{ Property } & 方 & $\stackrel{.}{\Xi}$ & 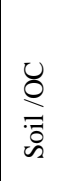 & \begin{tabular}{l} 
U \\
\multirow{1}{*}{} \\
$\overline{\overline{0}}$ \\
is
\end{tabular} & 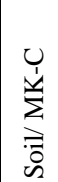 & 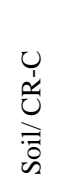 & 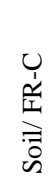 \\
\hline \multicolumn{9}{|c|}{ characteristics } \\
\hline \multicolumn{2}{|c|}{ Density( Unit weight) } & $\rho_{d}$ & $\mathrm{~g} / \mathrm{cm}^{3}$ & 1.64 & 1.65 & 1.65 & 1.67 & 1.66 \\
\hline \multicolumn{2}{|c|}{ Initial water content } & $w$ & $\%$ & 23.5 & 23.0 & 23.3 & 21.5 & 22.0 \\
\hline \multirow{3}{*}{ Atterberg's limits } & Liquid limit & $L L$ & $\%$ & 118 & 111 & 114 & 97 & 101 \\
\hline & Plastic limit & $P L$ & $\%$ & 35 & 33 & 33 & 30 & 31 \\
\hline & Plasticity. I & $P I$ & $\%$ & 83 & 78 & 81 & 67 & 70 \\
\hline \multicolumn{2}{|c|}{ AASHTOO Classification } & - & - & A-7 & A-7 & A-7 & A-7 & A-7 \\
\hline \multicolumn{2}{|c|}{ CBR } & - & $\%$ & 1.5 & 1.6 & 1.7 & 2.5 & 2.3 \\
\hline
\end{tabular}


TABLE V

\begin{tabular}{|c|c|c|}
\hline \multicolumn{3}{|r|}{ SOIL SAMPLE DEFINITION } \\
\hline No. & Soil label & Soil proportion definition \\
\hline 1 & $\mathrm{OC}$ & Original clay soil without improvement \\
\hline 2 & $\mathrm{~K}-\mathrm{C}$ & $20 \%$ kaolin \& $80 \%$ original clay soil \\
\hline 3 & MK-C & $20 \%$ Metakaolin \& $80 \%$ original clay soil \\
\hline 4 & FR-C & $\begin{array}{l}20 \% \text { Fine Recycled Brick \& } 80 \% \text { original clay } \\
\text { soil }\end{array}$ \\
\hline 5 & CR-C & $\begin{array}{l}20 \% \text { Corse Recycled Brick \& } 80 \% \text { original } \\
\text { clay }\end{array}$ \\
\hline 6 & OS & Original sand soil without improvement \\
\hline 7 & $\mathrm{~K}-\mathrm{S}$ & $20 \%$ kaolin \& $80 \%$ original sand soil \\
\hline 8 & MK-S & $20 \%$ Metakaolin \& $80 \%$ original sand soil \\
\hline 9 & FR-S & $\begin{array}{c}20 \% \text { Fine Recycled Brick \& } 80 \% \text { original } \\
\text { sand soil }\end{array}$ \\
\hline 10 & CR-S & $\begin{array}{c}20 \% \text { Corse Recycled Brick \& } 80 \% \text { original } \\
\text { sand }\end{array}$ \\
\hline
\end{tabular}

for the second original soil (OS) sieve analysis results show $17.15 \%$ passed from sieve No.200 $(0.075 \mathrm{~mm}), 83 \%$ passed from sieve No. $10(2 \mathrm{~mm})$ and $30 \%$ passed from sieve No. $40(0.42 \mathrm{~mm})$ the soil $(\mathrm{OS})$ did not give L.L \& P.L . According to AASHTO classification, the (OS) classified as class [A-1-b] sand, Excellent to good subgrade. It must be mentioned that using recycled materials to improve excellent to good subbase soil will be useful for air ports and high load traffic projects .Table (VI) shows the results of original clayey soil (OC) and four improved clayey soils.

Previous results show that clayey poor soil properties affected in very small values with the improvement of kaoline and metakaolin. Clayey soil also affected in values with crushed recycled refractory bricks. The kalcined clay did not change the classification class of poor clayey soil A-7. On the other hand it cannot be neglected that CBR ratio increased with $56 \%$ and $168 \%$ while soil improvement with fine and coarse recycled refractory brick respectively. The previous ratio of recycled materials plus getting rid of it make a positive ,economic and useful result of using recycled calcined clay in a comparison with soil stabilization with other material.

The results of sandy soil (OS) showed in table (6) the results show. Although CBR result of the original soil was good $(16.33 \%)$ but CBR results after improvement were so high especially when using fine and coarse recycled refractory bricks. the increase in CBR reached $56 \%, 168 \%$ for fine and coarse crushed recycled brick respectively. The previous CBR increase encourage to prepare A numerical study to discuss the effect of using waste recycled refractory crushed brick as a soil subbase material .

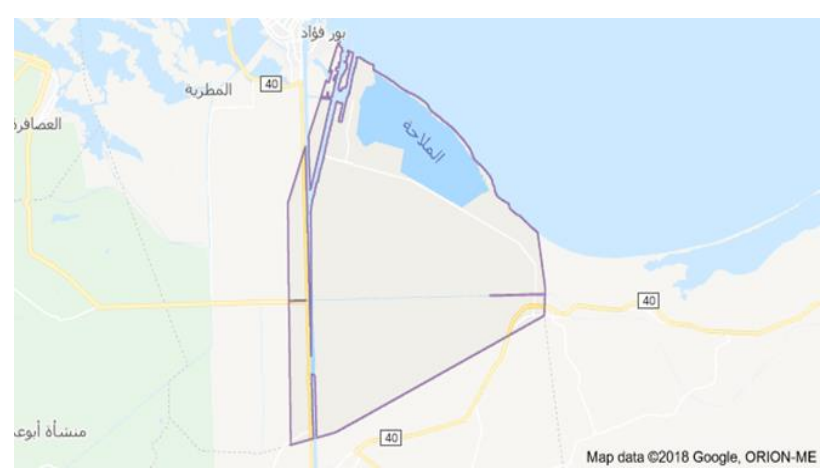

Figure 2. Soil sample site "Port Fouad"-Port Said, Egypt

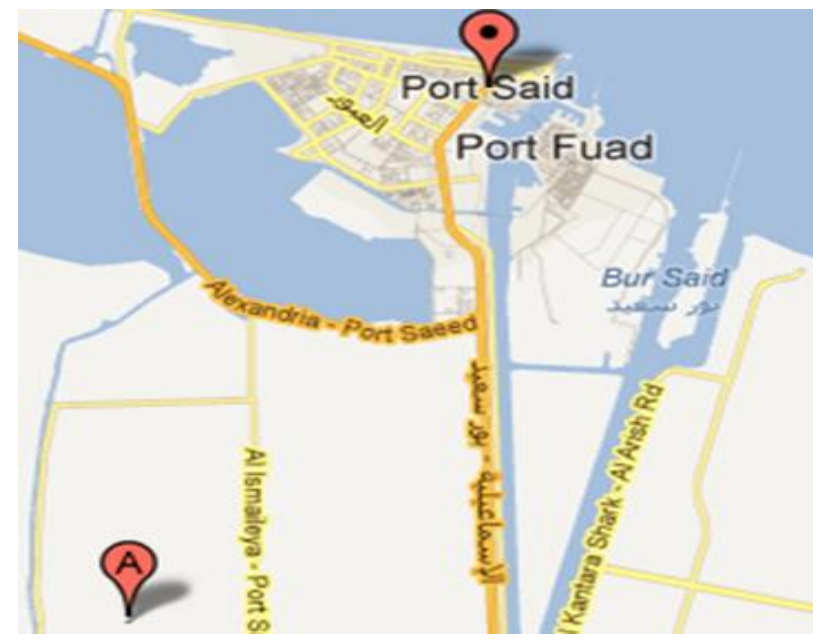

Figure 3. Soil sample site South Port Said, Egypt

TABLE (VI)

RESULTS OF ORIGINAL CLAYEY SOIL (OS) AND FOUR IMPROVED CLAYEY

\begin{tabular}{|c|c|c|c|c|c|c|c|}
\hline \multicolumn{8}{|c|}{ SOILS } \\
\hline Property & 方 & $\stackrel{\vec{\Xi}}{\vec{D}}$ & $\begin{array}{l}\circlearrowright \\
\stackrel{\circlearrowright}{0} \\
\stackrel{0}{0}\end{array}$ & 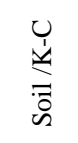 & 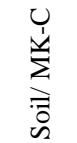 & 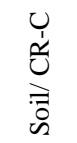 & 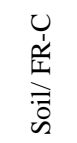 \\
\hline \multicolumn{8}{|c|}{ characteristics } \\
\hline Density( Unit weight) & $\rho_{d}$ & $\mathrm{~g} / \mathrm{cm}^{3}$ & 1.64 & 1.65 & 1.65 & 1.67 & 1.66 \\
\hline AASHTOO Classification & - & - & A-1-b & A-1-b & $A-1-b$ & $A-1-b$ & A-1-b \\
\hline CBR & - & $\%$ & 16.33 & 18 & 23.33 & 43.33 & 25 \\
\hline
\end{tabular}

\section{NUMERICAL STUDY}

A numerical application example prepared to discuss the behavior of an improved soil under loading as a sub base of high traffic load parking lot. The numerical study was carried out by ELPLA; it is a program for analysing slab foundations shallow or deep. Foundations can be in any shape with the real subsoil model. The mathematical solution of the slab is based on the finite element method. The program can analyse different types of subsoil models. The study uses 36 concrete pavement slabs to form a parking lot. The dimension of every slab was $(3.0 \mathrm{~m} * 3.0 \mathrm{~m} * 0.1 \mathrm{~m})$. The study makes the thickness of improved sub base soil under the slabs as a variable; it was taken from $1 \mathrm{~m}$ to $3 \mathrm{~m}$. In the numerical 
program two loading calculating types were used rigid pavement and elastic pavement.

The variables taken in the study were as follow:

1- Loading types were taken as rigid pavement or elastic pavement.

2- Load value was taken as 10, 20 and $50 \mathrm{KN}$ for rigid pavement type, and was taken as $1.1,2.2$ and $5.5 \mathrm{kN} / \mathrm{m}^{2}$ for elastic type as an equivalent to maximum load of transporting car in the slab area, loads take depending on the maximum loads due to high load transporting cars. Figure (II).

3- Five soil types were taken as a parameter; one of them was the original Soil (OS). The other four soils were the improved soils with different calcined clay types.

4- The thickness of improved soil layer. It have been taken $(0.1 \mathrm{~m}),(2.0 \mathrm{~m})$ and $(3.0 \mathrm{~m})$. Note: the improved soil layer varied (K-S), (MK-S), (FR-S) or (CR-S).

The first step was calculating modulus of compressibility (Es) for soil using results of CBR test the sample in the mold have confined sides except from the vertical direction which subjected to load. Stress strain relationship the modulus of soil deformation was calculated for five soil samples. Table (7) shows the modulus of deformation of soil samples.

TABLE (VIII)

MODULUS OF COMPRESSIBILITY OF SOIL SAMPLES.

\begin{tabular}{|c|c|c|}
\hline Soil type & Soil name & Modulus of compressibility \\
\hline $\begin{array}{c}\text { Without } \\
\text { improvement }\end{array}$ & OS & $\mathrm{E}_{\mathrm{S} 1}=8333$ \\
\hline $\begin{array}{c}\text { Kaolin } \\
\text { improvement }\end{array}$ & K-S & $\mathrm{E}_{\mathrm{S} 2}=21645$ \\
\hline $\begin{array}{c}\text { Metakaolin } \\
\text { improvement }\end{array}$ & MK-S & $\mathrm{E}_{\mathrm{S} 3}=14285$ \\
\hline $\begin{array}{c}\text { Fine recycled } \\
\text { improvement }\end{array}$ & FR-S & $\mathrm{E}_{\mathrm{S} 4}=25000$ \\
\hline $\begin{array}{c}\text { Coarse recycled } \\
\text { improvement }\end{array}$ & CR-S & $\mathrm{E}_{\mathrm{S} 5}=29410$ \\
\hline
\end{tabular}

\section{NUMERICAL STUDY RESULTS}

\section{A. Numerical results of rigid pavement loading type}

Figure (3) shows the percentage of settlement reduction while using fine crushed recycled refractory brick as a soil improvement material with concentrated load of $50 \mathrm{KN}$ on center of every slab .From the figure the reduction in settlement increases with the increase of soil improvement depth. Maximum settlement reduction reaches $94 \%$ at $3.0 \mathrm{~m}$ soil improvement.

Both maximum settlement reduction reached $97 \%$ at 3.0 $\mathrm{m}$ soil improvement depth for coarse recycled refractory brick. The maximum settlement reduction was $67 \%$ and $48 \%$ at $2.0 \mathrm{~m}$ and $1.0 \mathrm{~m}$ soil improvement respectively. The numerical analysis supports the laboratory result of useful effect of recycled refractory calcined clay. Figure (4) shows the reduction in settlement in case of using metakaolin as a soil improvement material. The maximum reduction in settlement was $78 \%, 52 \%$ and $27 \%$ when using $3.0 \mathrm{~m}, 2.0 \mathrm{~m}$ and $1.0 \mathrm{~m}$ improvement layer.

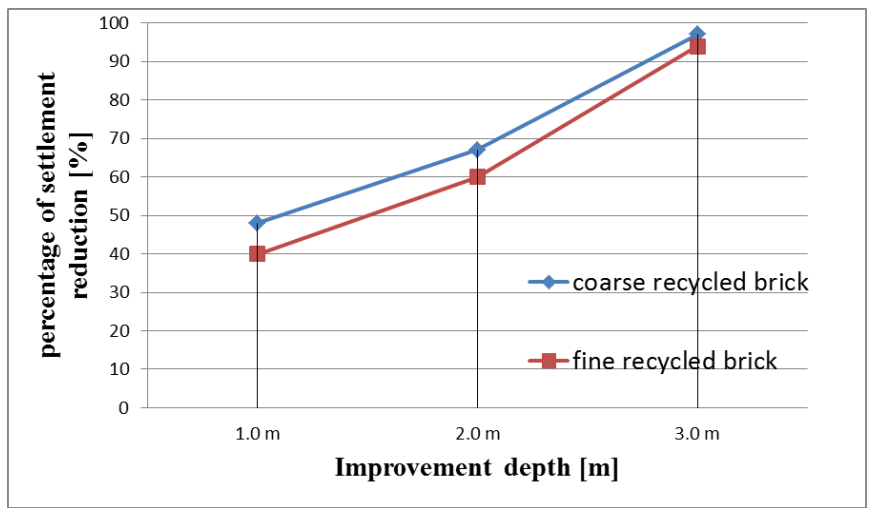

Figure. 2 Graded recycled refractory brick- rigid pavement

Also the previous figure shows the reduction in settlement in case of using kaolin as a soil improvement material. The maximum reduction in settlement was $91 \%, 62 \%$ and $32 \%$ when using $3.0 \mathrm{~m}, 2.0 \mathrm{~m}$ and $1.0 \mathrm{~m}$ improvement layer respectively.

TABLE (VII)

TRANSPORTATION CARS MAXIMUM LOADS

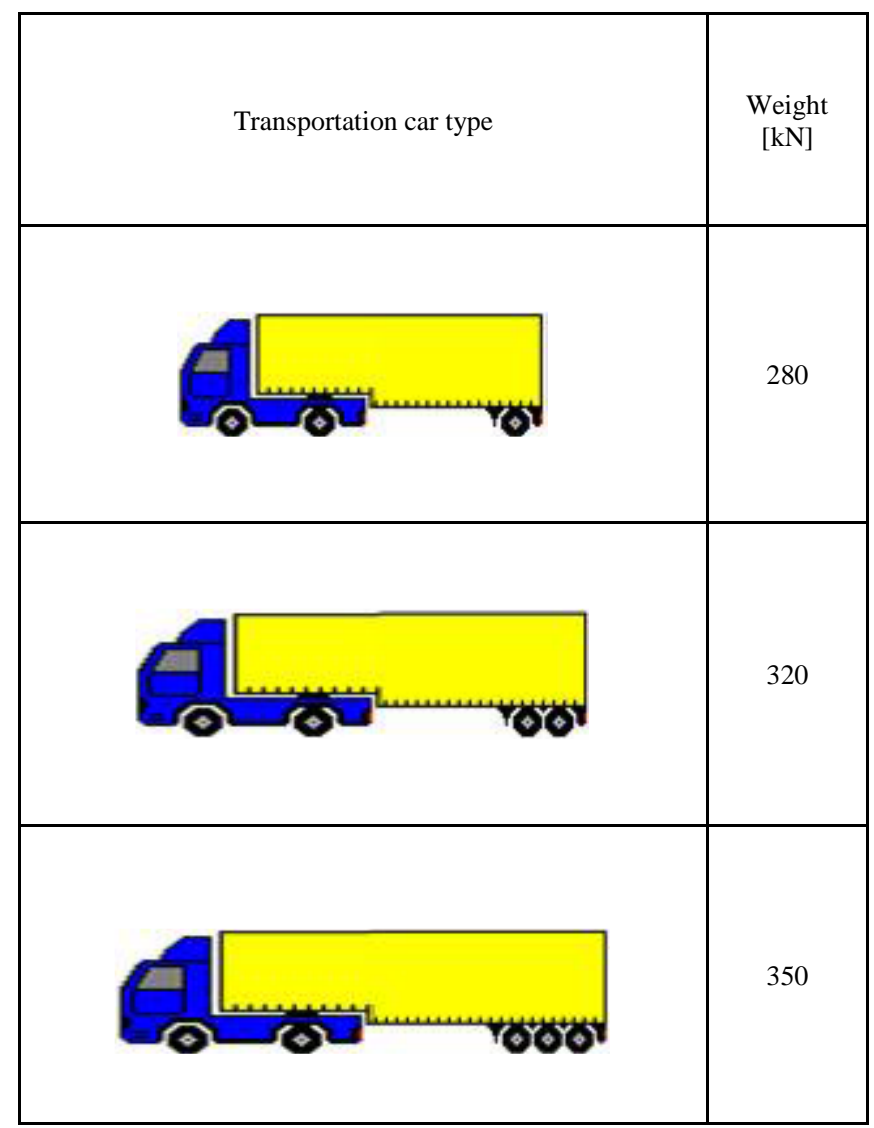




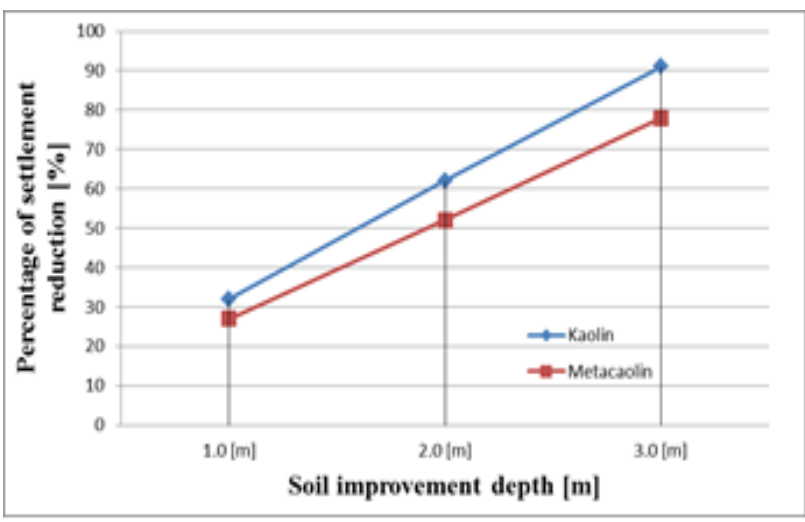

Figure .3 Settlement reduction (K-S) and (MK-S) $50 \mathrm{kN}$ rigid pavement

\section{Numerical results of elastic pavement loading type}

The 36 slabs were assumed to be subjected to uniformed load with three values. The loads were taken as $1.1 \mathrm{KN} / \mathrm{m}^{2}$, $2.2 \mathrm{KN} / \mathrm{m}^{2}$ and $5.5 \mathrm{KN} / \mathrm{m}^{2}$.

The thickness of subgrade layer was taken $1.0 \mathrm{~m}, 2.0 \mathrm{~m}$ and $3.0 \mathrm{~m}$. figure (5) shows the results of settlement reduction while using fine crushed recycled refractory brick as a soil improvement material. It observed that the maximum reduction in settlement while using $3.0 \mathrm{~m}$ improved soil with fine crushed recycled brick was $45 \%$. The maximum reduction in settlement was $21 \%$ while using $1.0 \mathrm{~m}$ improved soil.

The percentage of settlement reduction while using course crushed recycled refractory brick as a soil improvement material. The figures show that the maximum settlement reduction reaches $48 \%$ with 3.0 improved soils, $36 \%$ with 2.0 soils improved and $26 \%$ with $1.0 \mathrm{~m}$ improved soil.

Figure (6) shows the percentage of settlement reduction when using metakaolin as a soil improvement material at $5.5 \mathrm{KN} / \mathrm{m} 2$. The figure shows that the maximum settlement reduction reaches $30 \%$ with 3.0 improved soils, $23 \%$ with 2.0 soils improved and $14 \%$ with $1.0 \mathrm{~m}$ improved soil. The figure shows that the maximum settlement reduction reaches $42 \%$ with 3.0 improved soils, $31 \%$ with 2.0 soils improved and $22 \%$ with $1.0 \mathrm{~m}$ improved soil.

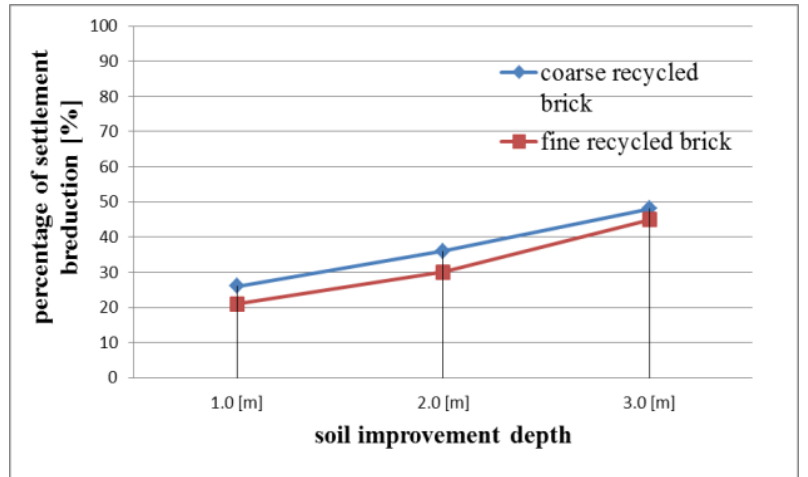

Figure. 4 Settlement reduction (FR-S ) and (CR-S) $50 \mathrm{kN}$ elastic pavement

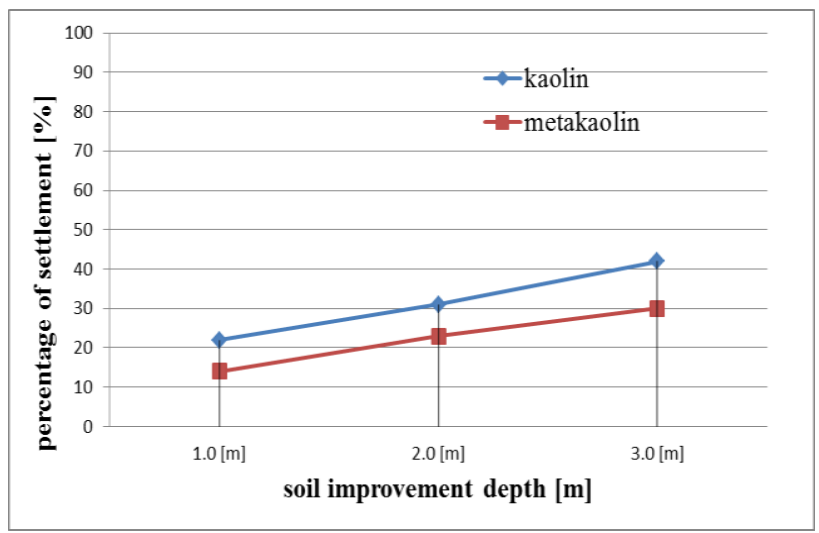

Figure .5 Settlement reduction (K-S) and (MK-S) $50 \mathrm{kN}$ elastic pavement

\section{CONCLUSION}

\section{A. Effect of recycled refractory brick in soil improvement}

1. The addition of recycled brick improves (CBR) ratio for sandy with high ratio for both clayey soil and sandy soil. the research recommended using recycled brick to increase CBR class for sandy soil.

2. Soil improvement by coarse crushed recycled refractory brick increases CBR ratio to $43 \%$ instead of $16.33 \%$ without improvement.

3. The study recommends using recycled refractory bricks as an economic improvement subbase stabilization material.

4. Using recycled refractory brick serves the environment by disposing of cement factories waste.

5. The result of numerical study shows that the maximum settlement reduction reached $97 \%$ at $3.0 \mathrm{~m}$ soil improvement depth with coarse crushed recycled refractory brick.

\section{B. Effect of Kaolin and Metakaolin in soil improvement}

1. Addition of kaolin or metakaolin increase CBR ratio in a small value

2. The reduction in settlement due to kaolin or metakaolin does not encourage using it as a stabilization materials for subbase soil.

3. These calcined clay types were studied in soil improvement to complement a previous study of properties of kaolin and metakaolin in construction application. But the study does not recommend using kaolin or metakalin in subbase improvement because its cost was may be greater than its advantages. 


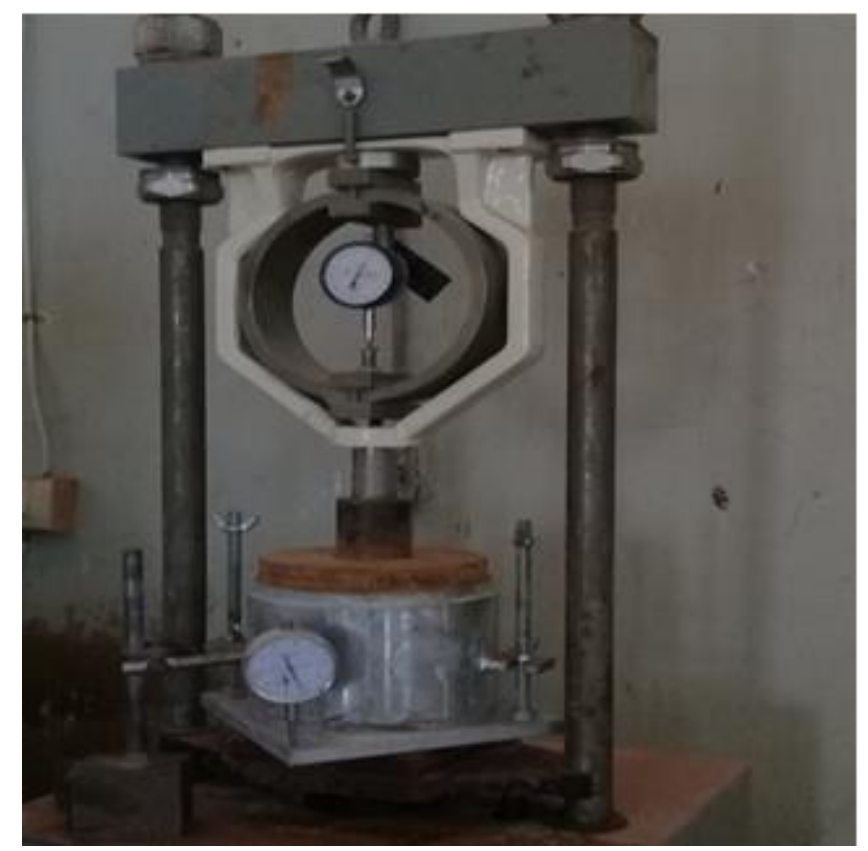

Figure .6 CBR test for samples

\section{REFERENCES}

[1] Gulsah Yesilbas," stabilization of expansive soils using aggregate waste, rock powder and lime ", master Thesis, the middle east technical university ,the school of natural and applied sciences ,2004.

[2] Kamon, M. and Nontananandh, S., "Combining Industrial Wastes with Lime for Soil Stabilization”, Journal of Geotechnical Engineering, Vol. 117, pp. 1-17,1991.

[3] Sabat, A.K. "A study on some geotechnical properties of lime stabilized expansive soil -quarry dust mixes, "International Journal of Emerging Trends in Engineering and Development, Vol.1( 2), pp 4249,2012.

[4] Sabat, A.K., and Nanda, R.P., "Effect of marble dust on strength and durability of rice husk ash stabilised expansive soil, " International Journal of Civil and Structural Engineering, Vol.1 (4), pp 939948,2011 .

[5] Ene, E., and Okagbue, C., "Some basic geotechnical properties of expansive soil modified using pyroclastic dust, " Engineering Geology, Vol.107(1-2), pp 61-65,2009.

[6] Abd EI-Aziz, M., and Abo-Hashema, M.A., "Measured effects on engineering properties of clayey subgrade using lime-homra stabiliser," International Journal of Pavement Engineering, DOI: 10.1080/10298436.2012.655739,2012.

[7] Binici, H., "Effect of crushed ceramic and basaltic pumice as fine aggregates on concrete mortars properties," Construction and Building Materials, Vol. 21, pp 1191$1197,2007$.

[8] Koyuncu, H., Guney, Y., Yilmaz, G., Koyuncu, S., and Bakis, R., "Utilization of Ceramic wastes in the construction sector," Key Engineering Materials, Vols. 264-268, pp 2509-2512,2004.

[9] P.Indiramma 1, Dr.Ch.Sudharani, Use of Quarry Dust for Stabilising Expansive Soil ,International Journal of Innovative Research in Science, Engineering and Technology, Vol. 5, Issue 1, Januray 2016. 